\title{
From Thaer and Thünen until Today: Past and Future of Agricultural Landscape Use in Germany
}

\author{
Harald Kaechele $^{1}$, Sunil Nautiyal ${ }^{2}$ \\ ${ }^{1}$ Leibniz-Centre for Agricultural Landscape Research (ZALF), Institute of Socioeconomics, Eberswalder, Muencheberg, Germany; \\ ${ }^{2}$ Centre for Ecological Economics and Natural Resources, Institute for Social and Economic Change, Nagarabhavi, Bangalore, India. \\ Email: nautiyal_sunil@rediffmail.com
}

Received October $12^{\text {th }}, 2010$; revised November $13^{\text {th }}, 2010$; accepted November $15^{\text {th }}, 2010$.

\begin{abstract}
This article intends to present the historical development of German agriculture sector over the last several decades and underlined the benefit of the advancement in agriculture sector to fulfill the growing food demand. At the same time the article discussed the ecological and socio-economic viewpoint of rapid technological development of agriculture sector in Germany. It would facilitate the debate on technological advancement in agriculture sector, which rapidly developing throughout the world, in the perspective of ongoing climate change and corresponding limit of sustainable socio-ecological development.
\end{abstract}

Keywords: Agricultural Landscape, Energy Efficiency, Sustainable Agriculture, Technological Development, Climate Change

\section{Introduction}

When Albrecht Daniel Thaer purchased the estate at Möglin in 1804, it was his intention to lay the foundations of rational agriculture. The highly successful physician had realised quite early that the low productivity of the agricultural and silvicultural land use of that time could be overcome by means of appropriate management systems [1]. Thaer criticised the poor soil culture of the agricultural lands. For years he had been sustaining the double work burden as physician and agronomist. But from 1804 on he devoted his activity exclusively to agricultural matters having in mind the improvement of the art of field husbandry by overcoming the deficiencies found in the way land was being managed. His 'Principles of Rational Agriculture' (1809-1812) published in four volumes, are generally regarded as the very foundation-stone of modern agricultural sciences [2]. Thaer perceived agriculture as an industry which would have to be performed in a sustainable and profit-orientated manner $[1,3]$. Thus he postulated two criteria which even 200 years after him have not lost any of their validity: Efficient agriculture, as we understand it today, is defined, to a considerable degree, by economic success. Furthermore, the idea of sustainability as demanded by Thaer, determines the current debate on land use even when this concept has experienced a significant impetus over the past decades. Thaer insisted on the long-term and durable perspective in farming which this concept implies. But today, against the background of the dramatic decline of the natural bases of life, the ecological dimension of our actions has increasingly come under public scrutiny. In principle, this does not question Thaer's demand for a rational agriculture, but is just made more precise in the light of recent developments and findings.

The evolution of agricultural land use has, since Thaer's times, revealed a hitherto unprecedented dynamics. Whilst until the mid-20th century not even 10 people were fed by one agricultural worker, this ratio was 1:126 in 2004 ! Since 1950 labour productivity in farming hence has been rising at an annual rate of over $6 \%$. Which have been the factors contributing to this unparalleled boost in productivity achieved over a few decades which allowed to overcome the deficient soil culture stated by Thaer? And how does the outcome of a 200-year evolution look like under the perspective of the sustainability postulate introduced by Thaer? This paper is intended to help answering these questions, i.e. to make a contribution in terms of reflecting the developments of Central-European agriculture starting with the situation as encountered by Thaer and further on until today's highly efficient agricultural production. It was at Möglin over 200 years ago where the foundations were conceived and later on deepened and further developed by the pupils of 
Albrecht Daniel Thaer, like Johann Heinrich von Thünen and Carl Philipp Sprengel.

\section{Fundamentals of Modern Land Use Systems}

Land-use change has been recognised as the major driving force altering vegetation patterns in the European landscape today [4-5] as cited in Muster et al., $2007 \mathrm{p}$. 1187 [6]. When addressing the question which factors proved to be decisive for the enormous productivity increases in agriculture, in a first approach one is, first of all, inclined to find an explanation within the agricultural sector. A second glance at history, however, reveals quite soon that, apart from these endogenous factors, developments outside agriculture, as, for example, in the transport sector, have helped considerably to bring about this change. Therefore, the following considerations will focus on developments outside the agricultural sector. In addition to endogenous factors of influence, these had a decisive bearing on it, the implications being discussed as well. Along with these factors very strongly dominated by technological developments it has been found that the policy interventions do likewise play an important part. Unless this role is properly understood, the change in agricultural land use will not be grasped. Political transformations which had a strong impact on landscape use were quite diverse. They range from the agricultural reforms of the mid-19th century - as those in Prussia - via the foundation of the German "Reich" in 1971 [7], the period of collectivisation on the territory of the former GDR being included, to the Common Agricultural Policy (CAP) in Europe which, in turn, is subject to a continuous, partly very drastic change. Not to go beyond the scope of this paper, in essence the impacts of the European Union's Agricultural Policy during the initial years of the European Community until today will be focussed.

\section{Developments inside Agriculture}

Until far into the last century the possibilities for agriculture in Central Europe to thrive were impaired by relatively tight restrictions. The farms were strongly bound to the site conditions of the natural space. Regionally adapted farm animal breeds and crop varieties evolved. This formed the background for the abundance of different local crop varieties and farm animal breeds to which has given birth the traditional farming sector in Central Europe. On-farm organisation was bound to the organic character of production. It was only through livestoc $\mathrm{k}$ farming or a wide crop rotation sequences that soil fertility could be enhanced. Livestock and crop farming were thus closely intertwined. A comprehensive formulation of this 'organism theory' was undertaken first by [8] in his work "Ökonomik des landwirtschaftlichen Betriebes" (Economics of the agricultural holding). Pro- ductivity increases were possible to a modest extent only.

The influence of transportation costs on land use had been described already by Johann Heinrich von Thünen in his main work "Der isolierte Staat" (The isolated State) [9]. In his second paragraph, Thünen says that the transportation worthiness of commodities depends on their durability and on the ratio of the commodities' value to their volume or weight. This led Thünen to conclude that easily perishable or transport-unworthy commodities must be grown near the consumer market whilst those goods whose transportation costs prove relatively low in relation to the realizable price, can be produced on locations more remote from the market. Thünen derived from this finding his famous 'Thünen circles' or 'rings' with a view to explain the distribution of land use around a market (see Figure 1). Because of expensive and, above all, time-consuming means of transport agriculture had been tied to local and regional, i.e., isolated markets. Furthermore, until the start of this century the farming sector had been embedded in an economic system that was characterised by hand labour and a productivity level attainable on that basis.

This form of land use proved decisive for the conversion of natural landscapes into man-made ones. Thus it also shaped the ecological heritage on which the modern form of land management is founded. In the following, the major development trends in modern land use will be discussed in regard to the utilisation and modification of ecological resources of the landscape.

\subsection{Soil Fertility}

In 1826, Philipp Carl Sprengel disproved the hitherto generally accepted humus theory of his teacher Thaer, see Sprengel 1828 [10]. As early as three decades before Justus von Liebig (1803-1873), he maintained that the soil's yielding capacity, i.e. soil fertility is not necessarily bound to the provision of organic matter. It was Liebig's merit that the theory of mineral fertilisation had been widely recognised and ultimately made its breakthrough in farming practice [11], which, according to [12], occurred around the year 1880. The starting point of the mineral theory was the finding that the yielding ability is determined by the availability of certain nutrients. This created the basis for breaking up the production cycle of a farm and to increase the productivity of a field by the supply of mineral nutrients, irrespective of the intra-farm relationships. This allowed to abandon the compulsory linkage between crop production and livestock farming (which so far had been the only source of nutrients). It was only thanks to Liebig's findings that agriculture has been able to develop production systems that could relinquish livestock farming. 


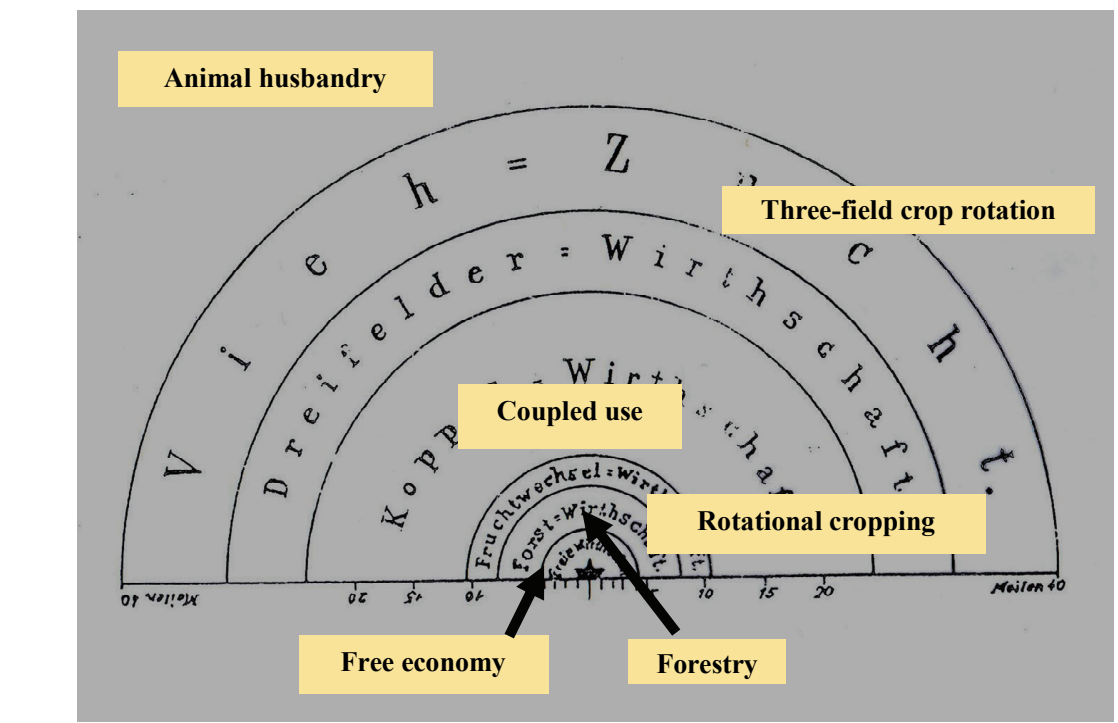

Source: J. H. von Thünen "Der isolierte Staat in Beziehung auf Landwirtschaft und Nationalökonomie" (1826). (Beschriftung Abb. 1, von oben nach unten)

(Livestock farming, Three-field rotation, Paddock farming, Crop rotation, Forestry, Free economy, Miles)

Figure 1. Thünen's model (circles or rings around the isolated market).

\subsection{Plant Health}

Likewise the origins of the modern phytomedical research date back to the mid-19th century. Anton de Bary who has been mainly devoted to the study of fungal diseases, presented his first work in 1853 [13]. Julius Kühn published some years later his comprehensive work "The Diseases of the Cultivated Plants, their Causes and their Prevention" [14]. Both men are considered as the founders of the phytopathological sciences. Sulphur and Pyrethrum were the first plant protection substances to be applied for the control of grape mildew and insect pests, respectively [15]. Previously, crop protection could be practiced only by means of duly adapted crop rotations or, as in the case of weed control, by costly hand labour. The inventions in the field of chemical crop protection allowed to reduce the formerly wide and multi-link rotations to the more profitable crop species. The use of cropprotection substances made it possible to free a rotation of those links which did not yield any or only small revenue contributions (e.g. fallow), but proved necessary for the sake of plant health. The rotations became narrower, with the share of market crops being increased and the impact on plant health being made up for by means of chemical methods.

\subsection{Breeding Progress}

The chance to make use of mineral fertilisers and crop protection chemicals also raised new challenges to plant breeders. They were now called upon to breed new crop plants which would be capable of meeting the new re- quirements. The fundamentals of modern plant breeding make use of the findings of the Austrian monk Gregor Mendel (1822-1884) [2]. By way of combination crossbreeding, mutation and hybrid breeding techniques it was possible to markedly enhance the potential productivity of crop plants [2]. The new varieties proved generally less robust. But under a well adjusted regime of the new production factors they were capable of greatly outyielding the conventional varieties. Agriculture was enabled to better adapt the sites to the crops whilst in the preceding centuries plant breeding was forced to adjust the crops to the site conditions of the respective region.

\subsection{Progress in Mechanisation Technology}

Due to the complete substitution of draft animals by motorised traction about one tenth of the farmland area formerly needed to feed draft animals was set free [16]. Market crops were grown now on these fields. The energy required for animal traction performance had not to be produced any more on the farm, but could be introduced into the system from outside. Properly speaking, the larger part of the problems discussed in this paper have been solved outside the farming sector, i.e. due to the contributions made by progress in engineering

\section{Developments outside Agriculture}

Two developments outside agriculture have had a decisive impact on the change in land use: the advances in the transport sector and the continuous rise in labour productivity of other branches of the economy. 


\subsection{Impact of the Modern Transport Sector on Land Use}

Thünen's assumptions were fundamentally altered by the technological progress in two aspects. On the one hand, the haulage of commodities was becoming increasingly faster and cheaper. The second aspect which has caused Thünen's premises to be substantially changed, relates to the area of conservation technology. Commodities that formerly used to be transportable over a short time and hence small distances only, can be moved nowadays over almost any distance.

\subsection{Influence on the Distribution of Land Use around a Market}

Thünen has demonstrated that the distribution of land use forms within a region will depend, first of all, on the possibilities of, and the resulting cost for transportation. He enlarged the former model of the circular arrangement of the agricultural landscape under the assumption that cheaper and faster means of transport become available, as, for example, that provided by a navigable river. Thünen's circles or rings are converted into bands under this assumption (see Figure 2).

Transportation and conservation techniques have allowed that the premises described by Thünen for the differentiation of land use around a market may increaseingly lead to the formation of bands of equal land use forms (e.g. belts in the USA). In Germany, the most important impulse concerning transportation systems traces back to the second half of the $19^{\text {th }}$ century, when the railway system was developed. German railway-systems cover app. $550 \mathrm{~km}$ in 1840 and were expanded to $11,660 \mathrm{~km}$ in 1860 and 37,650 in 1885 . The all-time high was reached in 1912 with a length of $58,297 \mathrm{~km}$. Motorways in former time did not play a comparable role. In 1935, Germany only possessed $108 \mathrm{~km}$ highways, but highway network was developed up to nearly 3,900 km in 1943 a level that was highest up to the late 1960s.

\subsection{Influences on the Markets}

The developments in the transport sector referred to above have also caused Thünen's assumption on the 'degree of isolation' of a market not to apply any more. When commodities can be exchanged cheaply between regions, countries and even continents this also implies that markets become virtually internationalised. This results in two significant changes of the traditional relationships between producers and consumers. The range of commodities offered to the consumers is markedly broadened by new products originating from other regions. Furthermore, the traditionally offered goods are now also made available by producers other than regional ones. The consumer may now choice between more products, and among the individual traditional products, between several suppliers. This causes the local producers to face competition on two levels. On the one hand, their products must compete with novel products attracting the purchasing power of the consumers, and, on the other, they must also compete with their own traditional

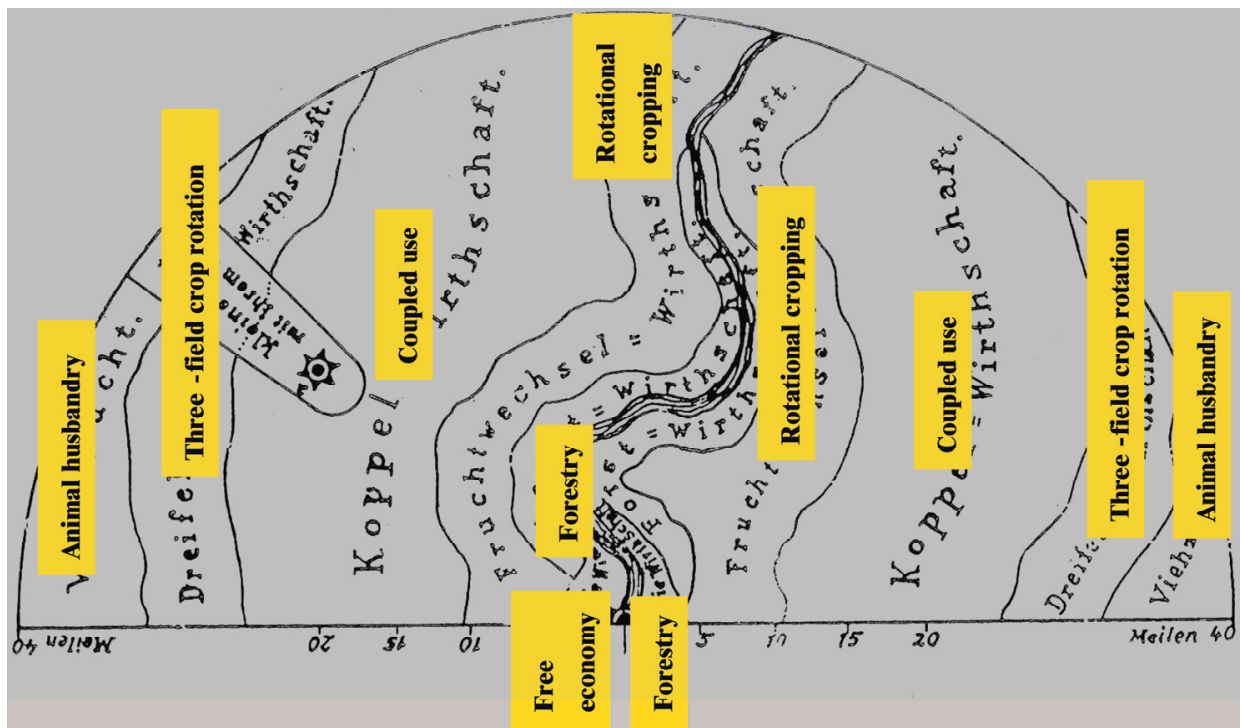

Abb. 2: Thünen's circles become bands under the assumption of cheap transport facilities source: J. H. von Thünen "Der isolierte Staat in Beziehung auf Landwirtschaft und Nationalökonomie" (1826).

(Livestock farming, Three-field rotation farming, Small town with its surrounds, Paddock farming, Crop rotation farming, Forestry, Free economy, Free economy, Forestry, Crop rotation farming, Paddock rotationalgrazing, Three-field rotation farming, Livestock farming, Miles))

Figure 2. Circles of Thünen's model become belts. 
products that originate from other manufacturers This forces them to make consistent use of comparative cost advantages and economy of scale effects.

\subsection{Utilising Comparative Cost Advantages}

The enterprises specialise in those products they can manufacture at a comparatively lower cost than the competitors. Economically, this phenomenon is called 'comparative cost advantage'. The theory of 'comparative cost advantages' was already maintained by Ricardo (1772-1823), a contemporary of Thaer [17]. Using the production of wine and cloth as examples he showed that it is reasonable for two countries to concentrate both on the product that they are capable of producing in the relatively cheapest way. Ricardo was able to prove by the examples of England and Portugal that this conclusion even applies when one country (Portugal) could produce both commodities more cheaply than the other one. In the light of the questions raised here, Ricardo's finding can be interpreted insofar that macro-economically reasonable developments tend to lead to an impoverishment of the diversity of productions in the respective regions.

\subsection{Utilising Economy of Scale Effects}

Not least the facilities created by the modern means of transport likewise allow to utilise scale effects in agricultural production. With regionally limited markets bound into the organic character of agricultural holdings, it was not possible to set up large structural units. Above all livestock farming was restricted due to these relationships. Under the new framework conditions it now became possible to also make use of so-called cost degreessions achievable in larger units of production. Behind this the phenomenon is concealed that the costs per unit of output first tend to fall as the installation grows in size. It is only from a certain critical size on that this phenolmenon is reversed.

\section{Societal Labour Productivity}

The various sectors of a national economy are intertwined through the labour and capital markets. In this context, the sector with the highest productivity exerts a kind of absorbent action vis-à-vis the other sectors During the pre-industrial phase, the productivity in all sectors was determined by the crafts sector. Industrialisation allowed labour productivity to be raised enormously. Over the times, the wages and incomes derived from employment in the industrial sector were continuously rising and, consequently, attracted outside labour. Considerable out-migration from the agricultural sector since World War II has been a clear evidence of this trend. Whilst after World War II 4.8 million people were still engaged in German agriculture, this figure has declined to under 0.9 million by 2004 [3]. As has been outlined above, agriculture was capable of achieving a relatively high degree of mechanisation. Modern agriculture replaces human labour by technological or chemical processes. Unlike the pure service-rendering sectors the agricultural sector is unable to share the general welfare growth by continuously raising the commodity prices, but due to the technical premises is obliged to achieve higher revenue claims via increased labour productivity as is the case with other sectors of the manufacturing industry. The pressure to implement productivity-raising measures, has been and still is quite substantial. As already mentioned before, agriculture has responded to this challenge by boosting labour productivity at an annual rate of more than $6 \%$ over the past 45 years.

\section{The Role of the Early EEC Policies}

The course of the future Common Agricultural Policy of the European Community was set just a few years following World War II. It was then the priority task of policy-making to ensure adequate food supplies to the population affected by several years of starvation. Food demand had to cope with a farming sector that was largely still in the stage of mixed farming ('Koppelwirtschaft'). The major items of know-how required for a substantial productivity boost in agriculture was available on large scale (see preceding sections). The manufacturing industries proved willing and, above all, capable to provide the necessary inputs (machinery, fertilisers, crop protection substances) at competitive prices. The transport networks had been improved considerably in the second part of the $19^{\text {th }}$ century and before the wartime period. It was now the task of policy to create the framework conditions for matching the enormous demand with an adequate supply of commodities. Right at the beginning, the European Economic Community had to provide the agricultural sector with incentives so that it would utilise the still idle potential to increase productivity. Consequently, the agricultural sector was being protected from international competition by means of a whole range of import levies, import quotas and commodity prices kept artificially above the world market level. Productivity was growing at a very dynamic rate. 30 years following EEC foundation farmers were able to meet 100 per cent of the food demand.

\section{The Sustainability of Agricultural Land Use against the Background of the Developments Described}

The factors described determining the productivity boost in land use may be grouped in three main trends of development. These are: Firstly, the continuous increase of the specific intensity; secondly, specialisation within 
farms and among regions, which ultimately results in a substantial expansion of international trade. In the sections following, these parameters will be summarised with their impacts on the ecological dimension of sustainability being outlined. A detailed debate on this subject was held in the mid-1980s inter alia by the German Expert Panel on the Environment and documented in a final expertise [18].

\subsection{Increasing 'Specific Intensity'}

The term 'specific intensity' describes the sum of activities performed by an agricultural enterprise with regard to one unit of output. The use of the so-called production factors designed to increase and secure yields, as for example mineral fertilisers, and crop protection substances, has caused and still causes increasing amounts of substances to be introduced into the biosphere. These cannot be metabolised or degraded. Apart from these matter inputs there have also been increasingly physical interventions in landscapes, inter alia due to drainage measures, abolishment of landscape-structural elements or the employment of larger and heavier machinery. The resulting ecological consequences are those described in the following section.

\subsection{Elimination of Particular Sites}

The increased application of mineral fertilisers has caused nutrient-poor sites to be over-fertilised or even eutrophicated. Elsewhere, wet locations were drained using modern techniques, and made accessible to crop cultivation. This kind of practise has done away with an increasing number of particular sites. Their disappearance is accompanied by the loss of the habitats of many plant communities adapted to these specific site conditions. Species extinction is largely attributable to this factor. Every plant species extinct implies the disappearance of another 40 associated animal species. The extent of species extincttion caused by farming activities is thus still multiplied.

\section{Input of Pollutants into the Biosphere}

\subsection{The Nitrate and Phosphate Problem}

The fertilisation of crops is generally related with the risk of nutrients being leached. The nutrients leached are bound to result, on the one hand, in increased groundwater loads, and, on the other, due to surface runoff, in the eutrophication of surface water bodies. When transported by surface waters the nutrients reach the oceans. The consequences of surface water eutrophication constitute a complex system which cannot be made further reference to in this paper.

\subsection{Phytosanitary Products in the Biosphere}

The biosphere is unable to fully degrade crop protection substances. Furthermore, a smaller or larger part of these products are likely to drift due to air circulation and are then introduced into ecosystems away from the cropland areas treated. These two phenomena cause crop protecttion substances and their metabolites to accumulate in the biosphere.

\section{Consequences of Growing Mechanisation}

\subsection{Soil Degradation}

Higher intensities of cropland use also involve the employment of ever more and more powerful farm machines. The increasingly mechanised land management has resulted in the development of larger and heavier machinery. Consequently, soil compactions lead to plant growth problems because the crops can hardly root in the compacted soil layers. In addition, soil compaction tends to enhance the risk of erosion caused by the action of water. Furthermore, wind erosion may occur, which is also caused by the removal of structural landscape elements by farming [19].

\subsection{Removal of Structural Landscape Elements}

Land management using large, powerful machinery requires an adequate spatial shaping of the agricultural landscape. Consequently, land consolidation schemes have caused structural landscape elements to be removed during the past decades. Large, uniformly shaped fields have emerged. Nevertheless it should be borne in mind that spatially large structured landscapes must not be seen as something negative in general. North-east Germany, in particular has traditionally had such largely spaced landscapes. There, species communities typical of steppe landscapes were able to establish. However, as development has proceeded, often such spatially large landscapes were completely stripped of their structural elements. This factor and land consolidation in smallstructured landscapes has contributed and still contrib.utes to species extinction and to the enhancement of erosion processes on such areas.

\section{Intra-Farm Specialisation}

In addition to raising the specific intensity, intra-farm specialisation has been a feature notable over the past decades. This has caused the formerly indispensable combination of livestock farming and crop husbandry (mixed farming) to be abandoned. Today, on good arable locations farms can do without keeping farm animals. The nutrients required for the soil are made available by purchasing mineral fertilisers. The previous role of forage growing in the cropping plan in terms of plant health for other crop rotations links, has been taken over in modern farming by crop protection substances. 
On the other hand, farms have emerged that are almost entirely engaged in livestock production. Such intensive livestock operations largely rely on purchased feedstuffs. In relation to their farmland area, they are overstocked, i.e. they keep more animals than would be ecologically sustainable. On such operations, it has become a problem to dispose of the large amounts of livestock excreta produced. Such operations are likely to add considerably to the climate degradation because they emit greenhouse gases.

\section{Specialisation among Regions}

In the meantime, agriculture has also come to specialise among regions. Ricardo's theory of the 'comparative cost advantage' can be demonstrated today when looking at the spatial distribution of agriculture. Arable farms without livestock have emerged, for example on the outstandingly fertile lands around Hildesheim and Magdeburg. They are contrasted by livestock-intensive farms, inter alia, in north-west and south-east Germany. The situation in the young federal states appears to be different. In all of them livestock farming has gone down to a historical low (see introductory chapter).

The specialisation among regions has resulted in a further impoverishment of the diversity of cropping on the various locations. Furthermore, the problem of farmyard manure disposal inside the livestock-intensive regions tends to be aggravated because the transfer of farmyard manure from livestock operations to arable farms will be feasible only when such farms are located not too far from each other.

\section{Increased International Trade}

Today's modern means of transport allow to exchange commodities in considerable amounts not only between the various regions. In 2005, the total value of commodities of Germany's agricultural primary production amounted to 38.1 billion $€$. In this same year, Germany imported food products (including those for further processing) to the value of 38.0 billion $€$ whilst Germany's food exports reached a volume of 27.3 billion $€$ [3]. Hence Germany imports food products equivalent to the value of agricultural commodities produced in this country and exports processed or unprocessed food items to the value of $75 \%$ of Germany's agricultural primary production. Likewise, the upstream sector (prior to agricultural production) is exchanging between regions or continents ever more commodities which are used in the agricultural production process. The importation of feedstuffs (without cereals) into Germany from non-EU countries has risen, for example, from 1.26 million tons in 1995 to 2.02 million tons in 2005 [20].

\section{Summarising}

As late as 200 years after Thaer, numerous developments inside and outside the agricultural sector have corroborated his ideas on the rational land management. The productivity of current land use in Germany has attained an unprecedented level. This applies to productivity per unit area, as well as to labour productivity. Whilst the former has risen fourfold over the past 100 years, labour productivity has even been increased 12.5 fold. International trade has grown dramatically. At present the commodity value of the food products imported into Germany is almost equivalent to the value of the agricultural primary production. Along these lines it was possible to feed more and more people, and this with a far greater reliability than in previous times. As an indicator for the success of this evolution might serve the fact that Central Europe has not experienced any faminelike food shortages since the 1950 s with the population still growing. Productivity had risen so sharply that the mid-1980s saw considerable agricultural surpluses. This then has actually made about $10 \%$ of the agriculturally usable land redundant for food production.

It became evident that these successes were achieved above all by breaking up the organic character of agricultural holdings. They were also possible because of the massive input of exogenous energy and substances. Whilst agriculture during the pre-industrial period had to operate more or less within closed matter cycles, now substantial amounts of exogenous substances and energy are introduced into the agricultural system. Among other things, this has caused energy productivity to decline considerably as against unit area and labour productivity levels. Both developments, changes in terms of energy input (see Figure 3) and the declined energy productivity in Germany's agriculture (see Figure 4) were highlighted as major findings in the Report by the Commission of Enquiry of the German Federal Parliament on the "Protection of the Earth's Atmosphere", presented in 1994 [21]. Because of the intensification of agricultural production the farming sector increasingly operates merely as a 'processor' of fossil energy sources.

Moreover, it was shown that the increase in specific intensity and the growing specialisation of farms and entire regions also result in considerable ecological consequences. To what extent all these negative external impacts still come up to the criteria of sustainable land management as postulated by Thaer, has to be seriously questioned. The findings allow to suggest that the growing dependence on finite energy sources and substantial negative external effects with regard to the ecological impacts of modern agriculture will constitute the price to be paid - at least for the time being - for high and stable 
food supplies.

The adaptability of the current system of agricultural production to the forthcoming scarcity in energy and raw material supplies and the imminent climate change will be major subjects to be dealt with by agricultural research over the coming years. The knowledge of the historical relationships and factors forming the basis of the current productivity level could provide clues to possible corrections in terms of the future of agricultural landscape use. Ways to address these problems could be found, in particular, with reference to specific intensity, in the specialisation on farm and regional levels, as well as in regard to transportation costs.

Finally, some considerations are presented with reference to the ongoing debate on, and the major mediumterm trends in agricultural landscape use. The data we have presented with the Figures 3 \& $\mathbf{4}$ is the current trend of the agriculture sector in Germany which is continued and need to be evaluated in terms of energy efficiency in a proper ways that lead to visualize the actual net energy consumption even after post harvesting of the agricultural produce.

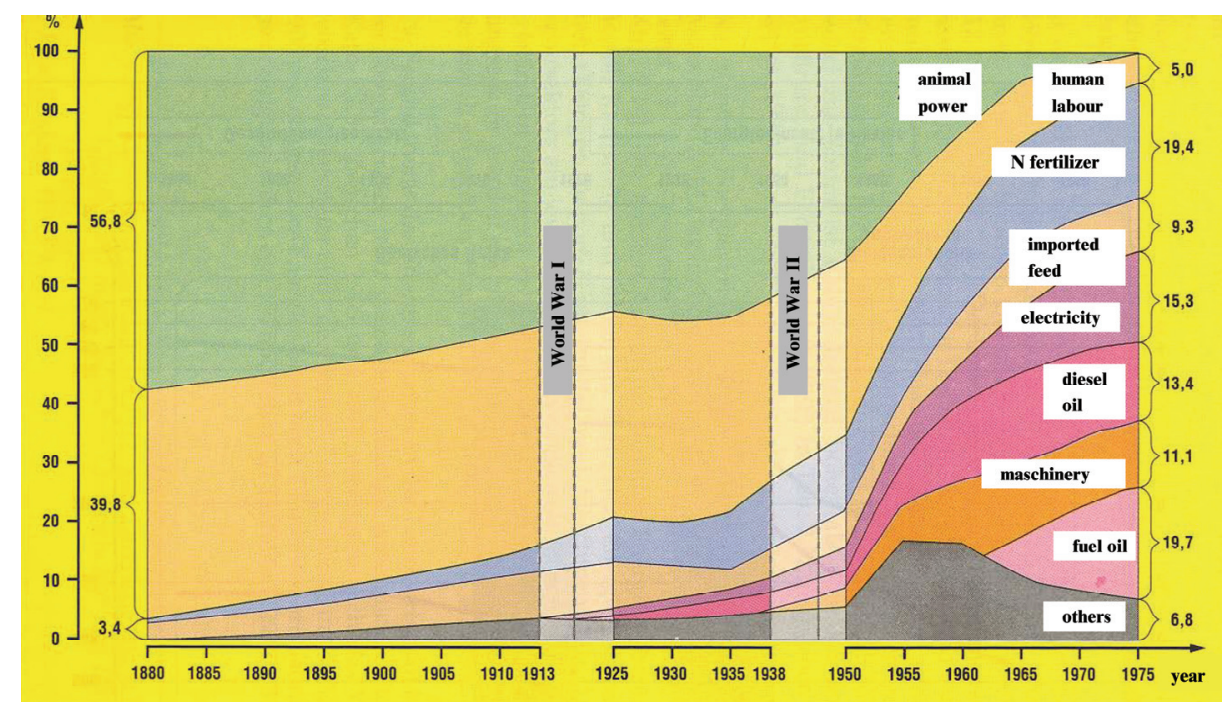

Source: Enquete-Kommission "Schutz der Erdatmosphäre" des Deutschen Bundestages "Schutz der Grünen Erde", 1994

Figure 3. Share of energy input of production factors in total energy input of German agriculture from 1880 to 1975.

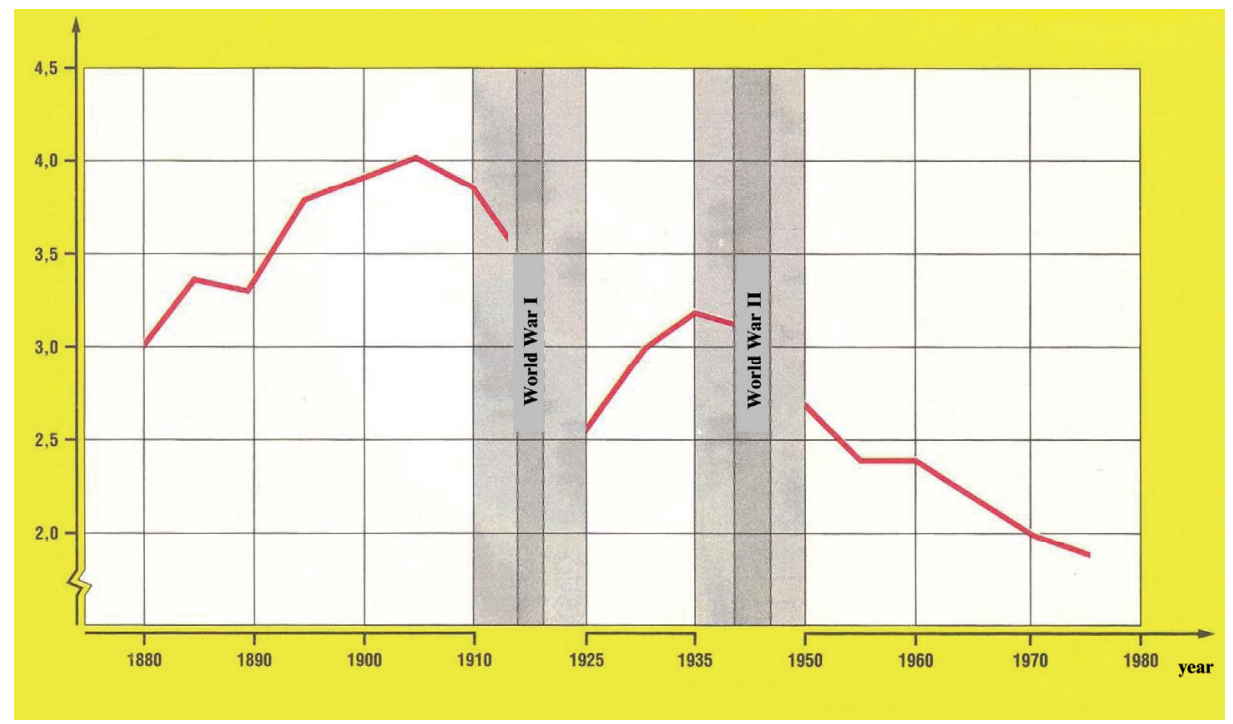

Source: Enquete-Kommission "Schutz der Erdatmosphäre” des Deutschen Bundestages "Schutz der Grünen Erde", 1994.

Figure 4. Efficiency of energy input (Joule gross land production per Joule energy input) in German agriculture from 1880 to 1975. 


\section{Determinants of Medium-Term Development}

It would go far beyond this survey paper to give a complete overview of the currently relevant determinants which, in line with the available knowledge, will in future influence agricultural landscape use. Therefore, reference will be made only to three factors which have proved crucial in the current debate: The impacts of EU agricultural policies, of the climate change and of genetic engineering, respectively.

\section{Impact of EU Agricultural Policies}

In view of foreseeable surpluses the agricultural policy of the European Union has been undergoing a fundamental change in the mid-1980s - leave behind the system of incentives to enhance productivity increases and move towards the reduction of surpluses. With a view to reaching this aim, on the one hand, the instrument of land set-aside was introduced and, on the other, commodity prices were gradually lowered to approach the worldmarket level. According to the common economic considerations, a commodity price reduction is expected to induce a distinct decrease in specific intensity. In making use of this instrument the EU has embarked upon a road entirely opposite to the one chosen 30 years before when agricultural output was being stimulated.

This step was also attributable to the rising tensions during the negotiations of the World Trade Organisation (WTO) which were aimed at advancing international free trade. Ultimately the negotiation parties came to the agreement during the last round not to allow any more government interventions which would directly result in competitive distortions [3]. Corresponding instruments such as tariffs or direct price subsidies were subsumed in a so-called 'Amber Box'. Instruments like area-related price compensation payments under the AGENDA 2000 or deficiency payments in the USA were grouped in the 'Blue Box' as tools partly permissible. Instruments being also in future fully compatible with the aims and rules of the WTO were subsumed in the so-called 'Green Box' This kind of instruments comprehend. e.g. agri-environmental measures, decoupled farm premiums without any relation to output, as well as infra-structural and regional development measures [3]. With a view to further ensure the promotion of agriculture and rural areas, the EU has started setting the course for shifting the support measures under the 'Amber Box' and the 'Blue Box', respectively, to the 'Green Box'. To this effect, the entire scheme of domestic agricultural support will be decoupled from production until 2013 (decoupling of area-related premiums). The premiums are linked to environmental standards (Cross Compliance) and funds from the so-called first pillar (compensation payments for agri- culture) were started to be shifted to the second pillar (promotion of rural development). This so-called modulation is expected to reach by $20135 \%$ of the current volume of support under the first pillar.

Last but not least substantial changes will result from the eastern expansion of the EU with her expenditure for agriculture being capped at the same time. On principle, it has been decided by the Council of Ministers that the total agricultural expenditure by the EU will in future be frozen to a level of approximately 42.3 billion $€ /$ year. The eastern expansion in 2004 by ten member states alone added another 38.6 million hectares of farmland to the EU's agricultural area. This is equivalent to about one fourth of the total farmland area of the old EU 15. A complete transfer of the previous support schemes to the new members is not possible because of the budget freeze agreed. Consequently, there will in future be distinctly less agricultural support money available per hectare.

On the whole it can be noted that the current agricultural policy of the EU tends towards a decoupling of production and a long-term reduction of the support level. Thus the EU's agricultural policy is likely to impart a clear impulse for a decrease of intensity in landscape use.

\section{Impact of the Climate Change}

The imminent climate change will impact the landscape use in two very distinct ways. On the one hand, the changing climatic indicators will alter the natural site conditions for agricultural production. This challenge can be addressed in two different ways. A shift could be produced in the range of crops grown towards crop species better adapted to the newly emerging climatic conditions. Such shifts are very likely to induce changes in the composition of the associated wildlife flora and fauna. Furthermore, plant breeders are currently attempting to genetically improve the crop species traditionally grown in a region. This is done to render them better adapted to the future conditions. These changes alike will imply corresponding responses of adaptation of the associated wildlife flora and fauna. This might, inter alia, open major approaches for genetic engineering research.

On the other hand, the imminent climate change clearly shows that an economic system based on fossil energy is running the risk of collapsing, not only because of the finite character of the fossil energy sources, but also on account of the disposal of the gaseous residues, in particular of $\mathrm{CO}_{2}$. That's why globally alternative energy sources are being looked after that would not affect the climate. Here, agriculture as a producer of renewable energy (reproducible raw materials) comes to play its part. It can be assumed that the farmland areas hitherto not required for food production will be used for growing 
energy crops. Hence, the release of land previously set aside will, above all, markedly enhance the intensity of landscape use.

The current energy and climate policies obey essentially the approach followed by the previous EU policy in the food sector, i.e. to stimulate output. Apart from the classical area-related premiums which are also paid for areas under energy crops and are funded out of the agricultural budget of the EU, currently farmers are eligible to additional incentives for the production of renewable raw materials. These are granted under several support schemes in energy policy (Energy Taxation Act, BioFuel Quota Act and Renewable Energy Act (EEG)). Due to the continuous overcompensation of the production costs for these energy sources, at present the cultivation of renewable raw materials is competitively stronger compared to food crops [22]. On account of the profitable support framework in Germany, raw materials from third countries are increasingly imported into the German market - with partly very serious ecological consequences in the countries of origin and replace the relatively dearer German-grown products [22]. These developments have been the reason for the current debate on the general revision of the support strategy for renewable energies derived from agriculture. However, this branch of the economy will be given, in principle, a markedly more important role than in the past, even under a changed support strategy with reduced payments because the problems related with energy supply and climate change tend to escalate.

The potentials of renewable energy sources from agriculture are currently being opened up step by step and, according to recent calculations, will come to attain about 500 to 1,000 PetaJ [ $\left.1 \mathrm{PJ}=10^{15} \mathrm{~J}\right]$ by the year 2050 . The strong variation of this estimate is essentially due to the uncertainty whether the arable land released can be used to grow bio-fuels with an inefficient energy yield or solid biomass fuels with a distinctly more efficient energy yield. Compared to the current annual primary energy demand in Germany of approximately $14.500 \mathrm{PJ}$, agriculture will be capable of meeting just 3.5 to $7 \%$ of this demand. Even when it should be possible until 2050 to sensibly raise the efficiency of energy consumption and to reduce it by $50 \%$, renewable energy sources could only account for merely 7 to $14 \%$ of primary energy consumption in Germany. These calculations reveal a broadly perceived misunderstanding as regards the availability of alternative energy sources derived from agriculture. Though the respective energy sources are renewable and thus are entirely different from fossil ones, they are not infinitely available. They will allow to meet only a (smaller) part of the energy demand of the industrialised world and are in this sense finite as well.

\section{Impact of Genetic Engineering}

Plant breeding using genetic engineering techniques is aimed at producing a new gene combination through the targeted insertion of alien genes into the gene structure of a cell or an organism, a procedure not being feasible by natural crossbreeding and/or natural recombination [23]. Contrary to the use of genetically modified organisms (GMO) in industry and medicine, being mostly performed in hermetically closed spaces, the application of GMO in agriculture is just based on their large-area release into the biosphere. That's why a broad debate is currently taking place on the benefits and hazards of 'green genetic engineering'. No detailed reference to this debate can be made here.

From the perspective of landscape use and landscape ecology, the Expert Panel on the Environment [24-25], however, has recognised a number of potential risks of GMO being released. But these have not yet been sufficiently studied by scientific research. Even when conclusive findings have not been available until now, it should be noted that the release of GMO does involve substantial impacts on the ecosystems of agricultural landscapes which could greatly alter the ecological integrity of these systems. As regards the practical relevance of green genetic engineering, the acceptance of this novel technology by the community of consumers and among farmers will be decisive. Genetically modified foods are rejected, according to an opinion survey conducted in 2005 , by $79 \%$ of the citizens in Germany [26]. A study in 2002 has revealed a similarly high rate of disapproval $(70 \%)$ among farmers in Germany [27]. Yet most recent studies have shown that at least the preparedness of farmers to use GMO for the cultivation of energy crops is markedly higher than in food production [28]. In general, it can be assumed that the very broad refusal of GM food by consumers will be much less pronounced when it comes to GM energy crops. Given the increased importance of growing energy crops, as already noted, under the impact of the imminent climate change and in view of the much higher acceptance of GMO by farmers in this field, a substantial expansion of the areas under GMO energy crops and thus stronger potential impacts on the agroecosystems are quite likely to happen.

\section{Conclusions}

Since World War II agriculture has been increasing labour productivity at annual rates of more than $6 \%$ over the past decades. This evolution has been enhanced by a number of technological innovations, but also thanks to massive support granted by agricultural policies. On account of this evolution full self sufficiency in food supplies to the population in the EU could be ensured on a 
durable basis since the mid-1980s. This implied impacts on the agro-ecosystems. The concomitant changes proved considerable. They are seen mostly in a critical manner by ecologists or natural scientists. Whilst technological progress has been more or less unchecked, agricultural policy has seen a radical change. Government support schemes for agriculture will in future be completely decoupled from output and, on medium term, be redirected towards agri-environmental measures and/or measures for the promotion of rural areas (European Agricultural Fund for Rural Development (EAFRD)). Thus agricultural policy is designed to provide incentives for a more extensive agricultural land use. Quite opposite signals are coming, however, from the German energy and climate policies. With the climate change being imminent and in view of the decline of the fossil energy reserves agriculture is coming to the fore as producer of renewable energy carriers. The current Government support policies in this sector are basically equivalent to price supports that have been granted to the food sector between the $1950 \mathrm{~s}$ and 1980s. Substantial incentives for a further intensification (the stronger use of GMO included) and specialisation of agricultural landscape use emanate from this kind of policy. As a first step, arable lands laid fallow over the previous years under set-aside schemes were reincorporated into intensive management. Moreover, it should be emphasized that the potential of renewable raw materials will at the current level just be capable of meeting 3.5 to $7.0 \%$ of the primary energy demand. Hence this kind of energy supply is reproducible, but proves quite limited in volume and, hence, finite as well. In view of the overcompensation in support programmes at present the legislative framework underlying this policy is being revised. Nevertheless, this does not alter the principally growing significance of this new branch for agriculture and the management of agricultural landscapes.

In summary, it can be assumed that despite the radical reverse in classical agricultural policy due to the enduring technological progress and the pressure to produce energy from alternative sources, the evolution in agricultural landscape use as occurred over the past 50 years is likely to continue. Consequently, a further intensification of production making full use of technological progress along with further specialisation among regions can be reckoned with. The potential consequences of this way of landscape use - often perceived quite critically - have been studied and described repeatedly in the past. They are not likely to change essentially in future.

\section{REFERENCES}

[1] Ma, Frielinghaus, Albrecht Daniel Thaer in BrandenburgBerlin, "Agrarhistorischer und kulturhistorischer Reiseführer, "Neuenhagen, 2004.
[2] E. R. Keller, H. Hanus and K.-U. Heyland, "Grundlagen der Landwirtschaftlichen Pflanzenproduktion," Stuttgart, 1997.

[3] DBV (Deutscher Bauernverband), "Situationsbericht 2006 - Trends und Fakten der Landwirtschaft," 2006.

[4] A. Cernusca, M. Bahn, C. Chemini, W. Graber, R. Siegwolf, U. Tappeiner and J. Tenhunen, "ECOMONT: A Combined Approach of Field Measurements and Process-Based Modelling for Assessing Effects of Land-Use Changes in Mountain Landscapes," Ecological Modelling, Vol. 113, No. 1-3, 1998, pp. 167-178.

[5] R. Waldhardt, D. Simmering and A. Otte, "Estimation and Predection of Plant Species Richness in a Mosaic Landscape," Landscape Ecology, Vol. 19, No. 2, 2004, pp. 211-226.

[6] S. Muster, H. Elsenbeer and M. Conedera, "Small-Scale Effects of Historical Land Use and Topography on PostCultural Tree Species Composition in an Alpine in Southern Switzerland," Landscape Ecology, Vol. 22, No. 8, 2007, pp. 1187-1199.

[7] H.-H. Müller, “ Die Brandenburgische Landwirtschaft von 1800 bis 1914/18 im Überblick," In: V. Klemm, G. Darkow and H. R. und Bork, Eds., Geschichte der Landwirtschaft in Brandenburg, Müncheberg, 1998, pp. 9-76.

[8] T. Brinkmann, "Die Oekonomik des Landwirtschaftlichen Betriebes," In: J. C. B. Verlag Mohr, Ed., Abteilung: Landund Forst-Wirtschaftliche Produktion, Versicherungen, Tübingen, 1992, pp. 27-124.

[9] J. H. von Thünen, "Der Isolierte Staat in Beziehung auf Landwirtschaft und Nationalökonomie," Hamburg, 1826.

[10] P. C. Sprengel, "Von der Substanz der Ackerkrume und des Untergrundes," In: Journal für Technische und Ökonomische Chemie, Leipzig, 1828.

[11] J. V. Liebig, "Die Organische Chemie in Ihrer Anwendung auf Agricultur und Physiologie," 1840.

[12] A. Fink, "Dünger und Düngung," Auflage, Weinheim, 1991.

[13] A. de Bary, "Untersuchungen über die Brandpilze," 1853.

[14] J. Kühn, "Die Krankheiten und Kulturgewächse: Ihre Ursachen und Ihre Verhütung," Bosselmann, 1858.

[15] H. Brammeier, "100 Jahre Biologische Bundesanstalt für Land-und Forstwirtschaft - Entwicklung und Organisation des Pflanzenschutzes in Deutschland," Braunschweig, 1998.

[16] M. Zimmermann, "Energieaspekte des Pferdeeinsatzes," Das Zugpferd, Vol. 2, No. 3, 1994, pp. 22-25.

[17] D. Ricardo, "On the Principles of Political Economy and Taxation,"John Murray, London, 1817.

[18] SRU (Sachverständigenrat für Umweltfragen), "Umweltprobleme der Landwirtschaft," Sondergutachten, Stuttgart, 1985.

[19] Schwäbisch Haller Agrarkolloquium zur Bodennutzung, "den Bodenfunktionen und der Bodenfruchtbarkeit," Für eine umweltfreundliche Bodennutzung in der Landwirtschaft, Gerlingen, 1994. 
[20] BMVEL, "Statistisches Jahrbuch über Ernährung, Landwirtschaft und Forsten," 2006.

[21] Enquete-Kommission Schutz der Erdatmosphäre, "Schutz der grünen Erde, Klimaschutz durch umweltgerechte Landwirtschaft und Erhalt der Wälder," Bonn, 1994.

[22] J. Hufnagel, "Nachwachsende Rohstoffe - eine Alternative für die Landwirtschaft? Aktueller Stand und Perspektiven," Vortrag im Rahmen einer Podiumsdiskussion zum Tag der Forschung innerhalb der Festwoche zur 775-Jahrfeier der Stadt Müncheberg, 2007.

[23] Europäisches Parlament und Rat, "Richtlinie 2001/18/EG über die Absichtliche Freisetzung Genetisch Veränderter Organismen in Die Umwelt," Amtsblatt der Europäischen Gemeinschaft Nr. L 106/1, 2001.

[24] SRU (Sachverständigenrat für Umweltfragen) Umwelt- gutachten 2004, "Deutscher Bundestag, Drucksache 15/ 36000," 2004(a).

[25] SRU (Sachverständigenrat für Umweltfragen), "Koexistenz sichern: Zur Novellierung des Gentechnikgesetzes," Kommentar zur Umweltpolitik, Vol. 4, 2004(b).

[26] FORSA (Gesellschaft für Sozialforschung und Statistische Analysen mbh), "Meinungen zum Verbraucherschutz, zum Lebensmittelangebot, zur Bezahlung der Bauern und zu gentechnisch veränderten Lebensmitteln," 2005.

[27] U. Brendel, "Deutsche Bauern lehnen Genpflanzen ab Ergebnisse Einer Repräsentativen Umfrage bei Landwirten," Hamburg, 2002.

[28] A. Künnemann, "Erfolgsbedingungen Gentechnikfreier Regionen," FH Eberswalde, Diplomarbeit, 2007. 